\title{
CANONICAL ANALYSIS OF COMMODITY FLOWS AND SOCIO-ECONOMIC STRUCTURE IN MAJOR U.S. METROPOLITAN AREAS
}

\author{
Mineaki KANNO*
}

\section{Introduction}

Transportation, by providing a means of moving people and goods to places where they can be more useful, permits locational specialization. The concentration of labor force and materials for manufacturing dan trade has been made possible by the development of transportation. The volume of all kinds of movements has increased in the recent past and the total volume of interurban circulation is conspicuous in urbanized societies. Cities are served by transporataion networks which make them accessible to other cities.

As the transport networks develop, the large cities acquire economies of scale, accelerate their growth, widen their markets, and increase their dominance in economic activities. Through such a development the large cities establish their hinterlands in which places are closely associated with the dominant cities. Functional and uniform regions are closely related facets of a broader pattern of spatial organization (Taaffe \& Gauthier, 1973, p. 69). Therefore a change in one brings about a change in the other through the mechanisms of regional specialization. If functional regions are delimited by patterns of commodity movements, some relationships may exist between functional regions and character of cities which may be revealed by their socio-economic structures.

In his study of Indian commodity flows, Berry (1966) employed canonical correlation analysis and found that commodity movements between trade blocks were associated with the attributes of trade blocks. McConnell (1967) found in his study of the Middle East that considerable interaction occurred among dissimilar regions, in terms of socio-economic characteristics. It is desirable that both socio-economic structure and spatial interaction patterns are treated, in dealing with spatial organization of regions. How, then, are socioeconomic characteristics of regions associated with interaction patterns? The aims of this paper are to identify commodity flow patterns and socio-economic structures of major U. S. metropolitan areas, and then to find the relationships between them.

\section{Method}

\section{Data}

Information on the flows of persons and commodities is obtainable from the Census of Transportation in the United States, but an areal breakdown of commodity movements is not adequate for a detailed geographic study. Although the Census of Transportation

\footnotetext{
* Department of Geography, University of Georgia, Athens, Georgia, U. S. A.
} 
does not provide thorough information on commodity flows among cities, the Census of Transportation, Volume III, provides origin/destination commodity flows among the production areas which have been developed in the Census of Transportation ${ }^{12}$. Each production area consists of one or more Standard Metropolitan Statistical Areas (SMSA), which make possible comparison between commodity flow data, and demographic and socioeconomic statistics available from other sources. Socio-economic data on the SMSA's are available from the County and City Data Book. Socio-economic data for each production area can be easily calculated from the data for the SMSA's in the production area.

Study area

The study area is confined to the 25 production areas (Fig. 1). It includes 70 SMSA's, Whose population accounts for 44 per cent of total population of the

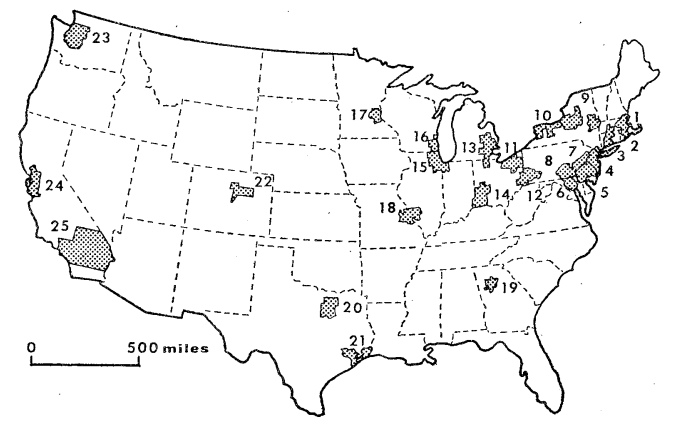

Fig. 1 Selected production areas

1. Boston, Mass. : Worcester, Mass. ; Providence-Pawtucket-Warwick, R. I.-Mass.; Brockton, Mass. ; Lawrence-Haverhill, Mass.-N. H. ; and Lowell, Mass.

2. Hartford, Conn.; New Britain, Conn,; Meriden, Conn.; Waterbury, Conn.; New Haven, Conn. ; Bridgeport, Conn. ; Norwalk, Conn.; Stamford, Conn.; and Springfield-Chicopee-Holyoke, Mass.-Conn.

3. New York, N. Y.

4. Newark, N. J. ; Jersey City, N. J. ; Paterson-Clifton-Passaic, N. J. ; and Middlesex and Somerset counties, N. J.

5. Philadelphia, Pa.-N. J. ; Wilmington, Del.-N. J.-Md. ; and Trenton, N. J.

6. Baltimore, $\mathrm{Md}$.

7. Allentown-Bethlehem-Easton, Pa.-N. J.; and Reading, Pa.

8. Harrisburg, Pa.; Lancaster, Pa.; and York, Pa.

9. Syracuse, N. Y.; Utica-Rome, N. Y. ; and Albany-Schenectady-Troy, N. Y.

10. Buffalo, N. Y.; and Rochester, N. Y.

11. Cleveland, Ohio; Akron, Ohio; Canton, Ohio ; Lorain-Elyria, Ohio ; Youngstown-Warren, Ohio ; and Erie, Pa.

12. Pittsburgh, Pa.; Steubenville-Weirton, Ohio-W. Va.; and Wheeling, W. Va.-Ohio.

13. Detroit, Mich.; Flint, Mich.; Toledo, Ohio-Mich.; and Ann Arobor, Mich.

14. Cincinnati, Ohio-Ky.-Ind.; Dayton, Ohio; Hamilton-Middletown, Ohio ; and Springfield, Ohio.

15. Chicago, Ill. ; and Gary-Hammond-East Chicago, Ind.

16. Milwaukee, Wis. ; Kenosha, Wis. ; and Racine, Wis.

17. Minneapolis-St. Paul, Minn.

18. St. Louis, Mo.-Ill.

19. Atlanta, Ga.

20. Dallas, Tex. ; and Fort Worth. Tex.

21. Houston, Tex.; Beaumont-Port Arthur-Orange, Tex. ; and Galveston-Texas City, Tex.

22. Denver, Colo.

23. Seattle-Everett, Wash. : and Tacoma, Wash.

24. San Francisco-Oakland, Calif.; Vallejo-Napa, Calif.; and San Jose, Calif.

25. Los Angeles-Long Beach, Calif. ; Anaheim-Santa Ana-Garden Grove, Calif. ; and San Bernardino-RiversideOntario, Calif.

Soure : Census of Transportation. 
United States. Fifty-two per cent of the manufacturing establishments in the United States is located in the production areas. Fifty-three per cent of all commodity shipments in the U.S. originate in these production areas. Thirty-one per cent of all shipments in the U. S. move among these production areas.

\section{Technique}

Factor analysis is helpful in identifying the main socio-economic structure of urban areas. It has been used in a considerable number of papers and books (for example, King, 1966 ; Murdie, 1969 ; Janson, 1971). Advantages of this approach include considerable objectivity and the ability to handle large amounts of data (Cole and King, 1968, p. 304). There are three main outputs from factor analysis : eigenvalues, factor loadings, and factor scores ${ }^{2)}$. Eigenvalues are measures of proportions of total variance, and are produced in decreasing order of importance. Thus, eigenvalues serve as highly efficient summaries of large data inputs. Factor loadings are measures of the association between the original variables and each factor. Each factor can be labeled according to the weight of factor loadings. Factor scores are measures of contribution of observational unit to each factor. Thus, factor analysis enables us to identify socio-economic dimensions of areas, and classify areas, in terms of those dimensions, using factor scores. And it is possible to find their spatial patterns.

According to R. H. T. Smith (1970), factor analysis is the most promising approach in order to find spatial structure of commodity flows. In this case factor analysis uses an origin/destination matrix. The original data matrix is $n \times n$ in which the cells contain measures of commodity flows between the paired places. Observation units as origins occupy the rows and other observation units as destinations occupy the columns. When R-mode factor analysis is applied to this data matrix, factor loadings and factor scores as well as eigenvalues are yielded. The factor loadings show which particular destinations are more typical of each type, or grouping. The factor scores show which particular origins are significant for destination groupings. This technique enables us to identify the commodity flow patterns.

When a Q-mode factor analysis is applied to the data, different commodity flow patterns may be identified. The Q-mode factor analysis transposes origins and destinations. The factor loadings give the identity of the more important origins associated with each group, and factor scores in turn show which destinations are more important for each group.

Socio-economic and commodity flow dimensions are revealed by these techniques. How can they be integrated ? Canonical analysis provides the means of identifying the relationships between socio-economic and commodity flow dimensions.

"Canonical correlation seeks to maximize the covariance or correlation between two sets of original variables, say $X$ and $Y$, by computing new variables, say $U_{k}$ and $V_{k}$ which are linear combinations of $X$ and $Y$, and are maximally correlated : $U_{k}=\alpha_{k} X$ and $V_{k}=\beta_{k} Y$, where $\alpha_{k}$ and $\beta_{k}$ are the coefficients of the resulting canonical vectors. The coefficients are like factor loadings for different dimensions, and the weight and sign can be used to indicate which of the original variables are to be cosidered, and the direction of their association ${ }^{32}$." 
Berry (1966) employed this technique in an attempt to find relationships between commodity movements and economic structures. Gauthier (1968) employed canonical correlation analysis in his study of economic growth of the São Paulo region, and three variables for urban economic development were matched against five dimensions of highway accessibility ${ }^{4}$.

\section{Findings}

\section{Demographic and socio-economic dimensions}

A total of 43 variables were used to find demographic and socio-economic dimensions (Table 1). These variables were then subjected to factor analysis in an attempt to reduce the variables into a significant number of basic dimensions, underlying the original 43 variables ${ }^{5}$. The factor analysis produced eight basic dimensions that together accounted for 87 per cent of the total variance of the data (Table 2). Varimax rotation is employed to make interpretation of the factors easier.

The first factor, accounting for 29 per cent of the total variance, is interpreted as a urban size dimension. High negative loadings occur on variables measuring numbers of manufacturing, retail, wholesale and service establishments, and total population. Areas with factor scores less than -1.0 are New York (-3.84), Los Angeles (-1.36), and Chicago $(-1.13)$ areas. Figure 2 shows spatial distribution of the factor scores. It reveals that New York, Los Angeles, and Chicago areas are leading urban areas in the United States.

Factor 2 shows that there are negatively high correlations with variables 7 (\% Negro population) and 21 (\% Negro occupied unit). This would indicate that this factor is associated with ethnic dimensions, or more specifically Negro population. Figure 3 shows that Atlanta $(-2.43)$ and Baltimore $(-1.58)$ are characterized by high Negro concentration. High positive factor scores on the areas in New England and New York indicate that Negroes are less concentrated in these metropolitan areas.

Factor 3 is positively associated with variables 30 (\% employed in government), 31 ( \% employed in professional and managerial), 32 (\% employed in sales and clerical) and 12 (\% completed 4 years of college or more, 25 years old and over), and negatively with 25 (\% employed in manufacturing) and 33 (\% employed in craftsmen and foremen). This factor may be labled as service activities. Denver (2.01), Atlanta (1.43), San Francisco (1.40), and Syracuse-Rome (1.01) areas have factor scores greater than 1.0 (Fig. 4).

Factor 4 is positively highly correlated with variables 16 (family income over $\$ 15,000$ ) and 39 (retail sales per establishment). The variables 16 and 39 may be associated with each other. The greater the per cent of family income over $\$ 15,000$, the greater the retail sales per establishment. Thus, this factor is interpreted as family income. The areas having factor scores greater than 1.0 are Chicago (1.59), Minneapolis-St. Paul (1.54), Detroit (1.54), and Newark-Jersey City (1.07) areas (Fig. 5).

Factor 5 is positively correlated with variable 19 (average persons per occupied unit) and negatively with variable 23 (\% labor force, 16 years old and over). Other variables have low factor loadings. This factor is interpreted as population density per dwelling unit. 
Philadelphia (3.32), Baltimore (1.48), and Syracuse-Rome (1.03) areas have high factor scores (Fig. 6). These places are relatively old cities.

Factor 6 is positively correlated with variables 6 (sex ratio), 36 (\% of production workers), and negatively with 24 (\% unemployed). This factor may be labled as an employment dimension. Figure 7 shows that Hartford (1.05) has a good employment opportunity. In turn, Seattle, San Francisco-Oakland, and Los Angeles areas have high unemployment rates.

Table 1 Selected demographic and socio-economic variables

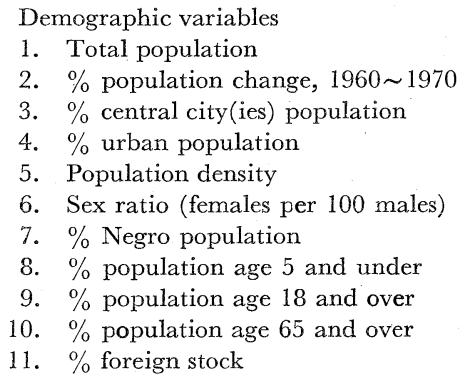

Social variables

12. \% completed 4 years of college or more, 25 years old and over

13. Population per household

14. $\%$ female head

15. $\%$ family income less than $\$ 3,000$

16. \% family income over $\$ 15,000$

17. Per capita money income

18. \% owner occupied unit

19. Average persons per unit

20. $\%$ lacking some or all plumbing facilities

21. $\%$ Negro occupied unit

22 . $\%$ units with air conditioning

Economic variables

23. $\%$ labor force, 16 years old and over

24. $\%$ unemployed

25. \% employed in manufacturing

26. $\%$ employed in wholesale and retail

27. $\%$ employed in service

28. $\%$ employed in educational service

29. $\%$ employed in construction

30. $\%$ employed in government

31. $\%$ employed in professional and managerial

32. $\%$ employed in sales and clerical

33. \% employed in craftsmen and foremen

34. Per capita bank deposits, June, 1970.

35. Number of manufacturing establishments

36. $\%$ of production workers

37. Value added by manufacture per worker

38. Number of retail establishments

.39. Retail sales per establishment

40. Number of selected services establishments

41. Selected services sales receipt per establishment

42. Number of wholesale establishments

43. Wholesale sales per establishment

All variables are based on the County and City Data Book, 1972, U. S. Department of Commerce, Bureau of the Census. 
Table 2. Factor loadings (Varimax rotation)

\begin{tabular}{|c|c|c|c|c|c|c|c|c|}
\hline Variables & I & II & III & $\begin{array}{c}\text { Factors } \\
\text { IV }\end{array}$ & $\mathrm{V}$ & VI & VII & VIII \\
\hline$I$ & $(-0.92)$ & -0.14 & -0.05 & 0.11 & 0.10 & -0.17 & -0.00 & -0.00 \\
\hline 2 & 0.25 & -0.29 & $(0.57)$ & 0.17 & -0.37 & -0.14 & -0.12 & 0.47 \\
\hline 3 & -0.40 & -0.01 & 0.13 & 0.08 & -0.10 & 0.07 & -0.17 & $(0.75)$ \\
\hline 4 & -0.48 & -0.08 & 0.32 & 0.41 & -0.16 & -0.20 & 0.25 & 0.40 \\
\hline 5 & $(-0.78)$ & -0.11 & 0.10 & 0.12 & -0.03 & 0.30 & -0.11 & -0.26 \\
\hline 6 & -0.35 & -0.01 & -0.10 & -0.19 & 0.06 & $(0.66)$ & 0.35 & -0.39 \\
\hline 7 & -0.24 & $(-0.82)$ & -0.03 & 0.13 & 0.20 & 0.14 & -0.05 & $0.30^{\circ}$ \\
\hline 8 & 0.26 & -0.23 & 0.15 & 0.32 & 0.04 & 0.15 & 0.35 & $(0.72)$ \\
\hline 9 & -0.46 & 0.20 & 0.04 & -0.25 & -0.14 & -0.03 & -0.40 & $(-0.68)$ \\
\hline 10 & -0.31 & $(0.53)$ & $-0.29^{\circ}$ & -0.30 & 0.10 & 0.18 & 0.05 & $(-0.61)$ \\
\hline 11 & $(-0.70)$ & 0.44 & 0.03 & 0.21 & 0.10 & -0.10 & -0.17 & -0.28 \\
\hline 12 & -0.08 & 0.30 & $(0.74)$ & 0.33 & -0.10 & 0.01 & -0.12 & 0.14 \\
\hline 13 & 0.06 & 0.06 & 0.09 & -0.02 & 0.18 & -0.04 & $(0.78)$ & -0.05 \\
\hline 14 & $(-0.69)$ & -0.41 & 0.29 & 0.07 & 0.35 & 0.13 & 0.01 & -0.19 \\
\hline 15 & -0.29 & $(-0.63)$ & 0.18 & $(-0.58)$ & 0.09 & -0.07 & 0.09 & 0.27 \\
\hline 16 & -0.43 & 0.04 & 0.26 & $(0.8 I)$ & 0.01 & -0.09 & -0.11 & 0.07 \\
\hline 17 & $(-0.57)$ & 0.02 & 0.29 & $(0.63)$ & -0.26 & -0.23 & -0.17 & -0.09 \\
\hline 18 & $(0.69)$ & 0.21 & -0.17 & -0.25 & 0.21 & -0.11 & 0.04 & -0.02 \\
\hline 19 & 0.19 & -0.15 & -0.11 & 0.09 & $(0.79)$ & 0.20 & 0.06 & 0.04 \\
\hline 20 & 0.33 & -0.03 & -0.31 & $(-0.58)$ & -0.20 & 0.09 & 0.20 & -0.41 \\
\hline 21 & -0.24 & $(-0.88)$ & -0.07 & -0.06 & 0.25 & 0.01 & 0.02 & 0.14 \\
\hline 22 & 0.02 & -0.48 & -0.06 & -0.11 & -0.42 & 0.48 & 0.14 & 0.41 \\
\hline 23 & 0.07 & 0.13 & 0.09 & 0.28 & $(-0.79)$ & 0.38 & -0.19 & $0.02^{\circ}$ \\
\hline 24 & -0.13 & 0.12 & 0.18 & 0.17 & 0.03 & $(-0.88)$ & 0.14 & -0.04 \\
\hline 25 & 0.11 & 0.22 & $(-0.89)$ & 0.13 & 0.09 & 0.07 & -0.13 & -0.25 \\
\hline 26 & 0.13 & -0.31 & $(0.56)$ & 0.07 & -0.22 & -0.14 & 0.46 & 0.35 \\
\hline 27 & -0.30 & $(-0.50)$ & $(0.60)$ & -0.04 & -0.31 & -0.08 & -0.02 & 0.35 \\
\hline 28 & 0.11 & $(0.62)$ & $(0.57)$ & 0.00 & 0.33 & -0.23 & 0.19 & 0.01 \\
\hline 29 & 0.37 & -0.31 & 0.40 & -0.38 & $-0.1 I$ & 0.05 & -0.22 & $(0.52)$ \\
\hline 30 & -0.01 & 0.05 & $(0.74)$ & -0.02 & 0.32 & -0.17 & 0.01 & -0.15 \\
\hline 31. & -0.16 & 0.13 & $(0.89)$ & 0.21 & -0.07 & -0.22 & 0.02 & 0.15 \\
\hline 32 & -0.44 & -0.27 & $(0.75)$ & 0.31 & -0.10 & 0.15 & 0.11 & 0.05 \\
\hline 33 & 0.43 & -0.11 & $(-0.70)$ & -0.23 & 0.17 & -0.28 & -0.09 & 0.18 \\
\hline 34 & $(-0.82)$ & 0.18 & 0.20 & -0.16 & -0.06 & 0.22 & 0.01 & -0.07 \\
\hline 35 & $(-0.97)$ & -0.05 & 0.01 & 0.04 & -0.06 & -0.02 & -0.03 & -0.03 \\
\hline 36 & 0.13 & -0.02 & $(-0.59)$ & -0.22 & 0.06 & $(0.57)$ & -0.17 & -0.19 \\
\hline 37 & 0.10 & -0.19 & 0.05 & -0.16 & 0.05 & -0.19 & -0.04 & $(0.70)$ \\
\hline 38. & $(-0.96)$ & -0.10 & -0.00 & 0.02 & 0.04 & -0.13 & -0.04 & 0.00 \\
\hline 39 & 0.04 & -0.15 & 0.15 & $(0.78)$ & -0.04 & -0.25 & 0.32 & 0.10 \\
\hline 40 & $(-0.93)$ & -0.09 & 0.02 & 0.02 & -0.04 & -0.18 & -0.02 & 0.03 \\
\hline 41 & $(-0.79)$ & -0.28 & 0.24 & 0.23 & -0.02 & 0.08 & 0.25 & 0.08 \\
\hline 42 & $(-0.97)$ & -0.10 & 0.07 & 0.00 & -0.05 & -0.01 & 0.03 & 0.01 \\
\hline 43 & -0.25 & $(-0.58)$ & 0.17 & 0.45 & -0.10 & 0.02 & 0.48 & 0.09 \\
\hline Eigenvalues & 12.53 & 8.36 & 5.38 & 2.98 & 2.88 & 2.35 & 1.51 & 1.38 \\
\hline $\begin{array}{l}\text { Cumulative } \\
\text { proportion of } \\
\text { total variance }\end{array}$ & $29 \%$ & $49 \%$ & $61 \%$ & $68 \%$ & $75 \%$ & $80 \%$ & $84 \%$ & $87 \%$ \\
\hline
\end{tabular}

Loadings greater than an absolute value of 0.50 are shown in parentheses.

Factors with eigenvalue qreater than 1.0 are rotated. 


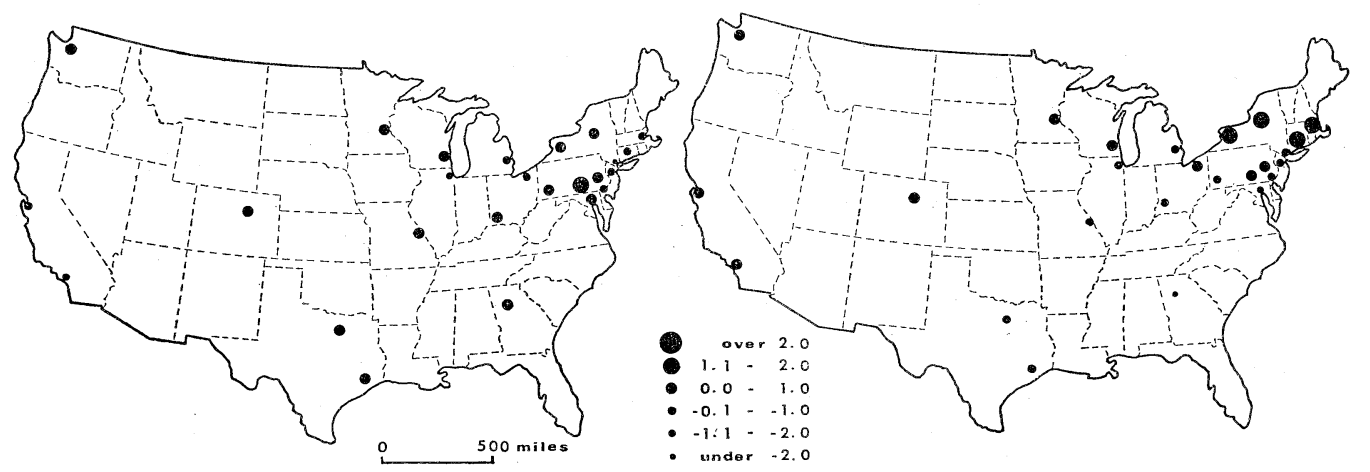

Fig. 2 Factor scores on factor 1

Wig. 3 Factor scores on factor 2

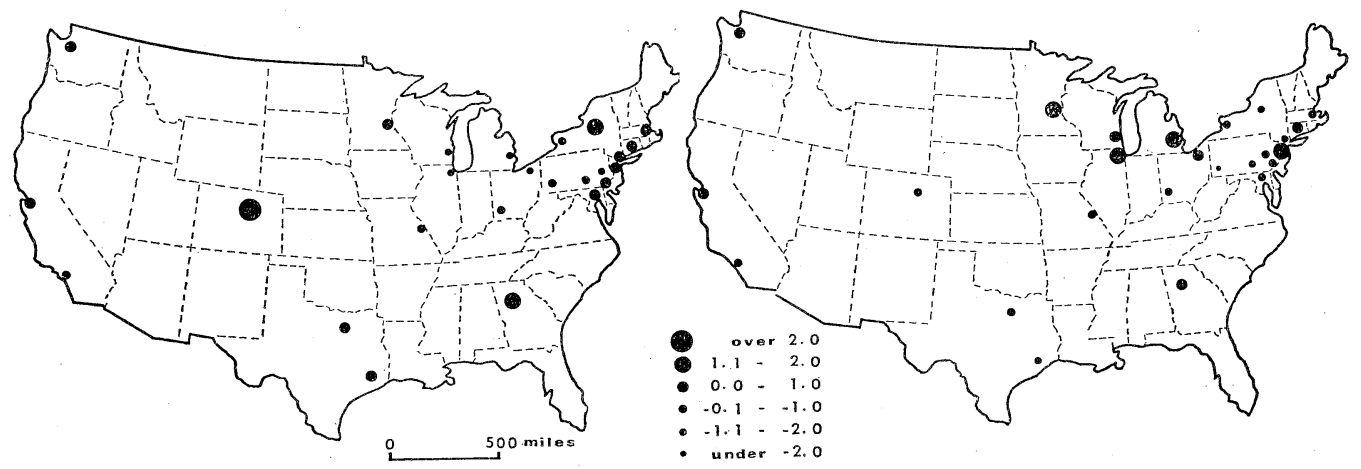

Fig. 4 Factor scores on factor 3

Fig. 5 Factor scores on factor 4

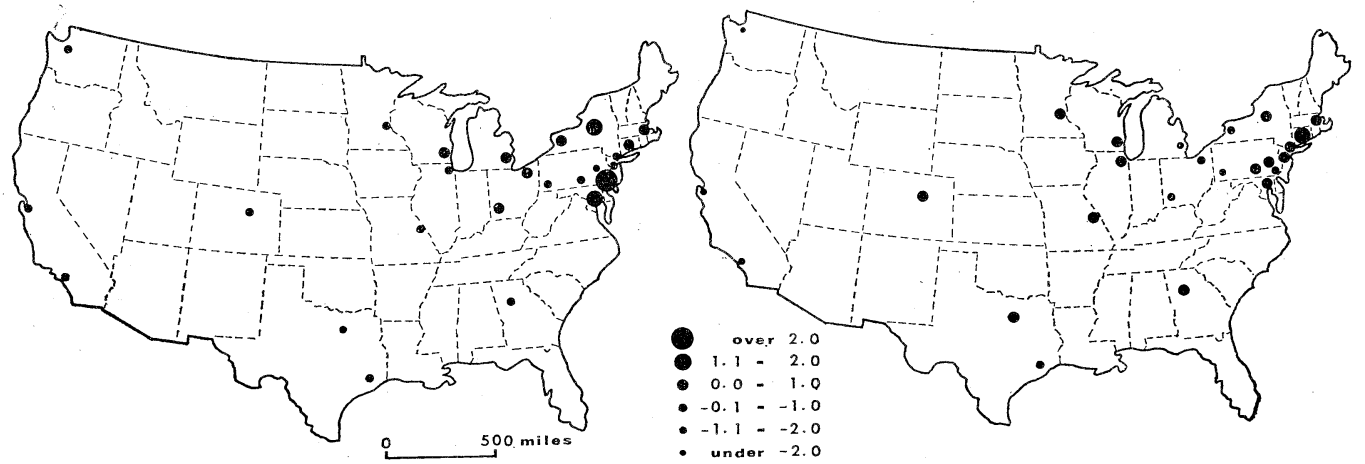

Fig. 6 Factor scores on factor 5

Fig. 7 Factor scores on factor 6

Factor 7 is positively associated with variable 13 (population per household). Other variables show low factor loadings. This factor is labled as family size. St. Louis (3.04) and Minneapolis-St. Paul (1.90) areas have high factor scores (Fig. 8).

Factor 8 is positively correlated with variables 3 ( $\%$ central city population), 8 ( $\%$ population age 5 and under), and 37 (value added by manufacture per worker). This factor may be interpreted as urban growth through manufacturing. Figure 9 shows that Houston (3.35) and Dallas (1.39) areas are fast growing areas in the nation. 


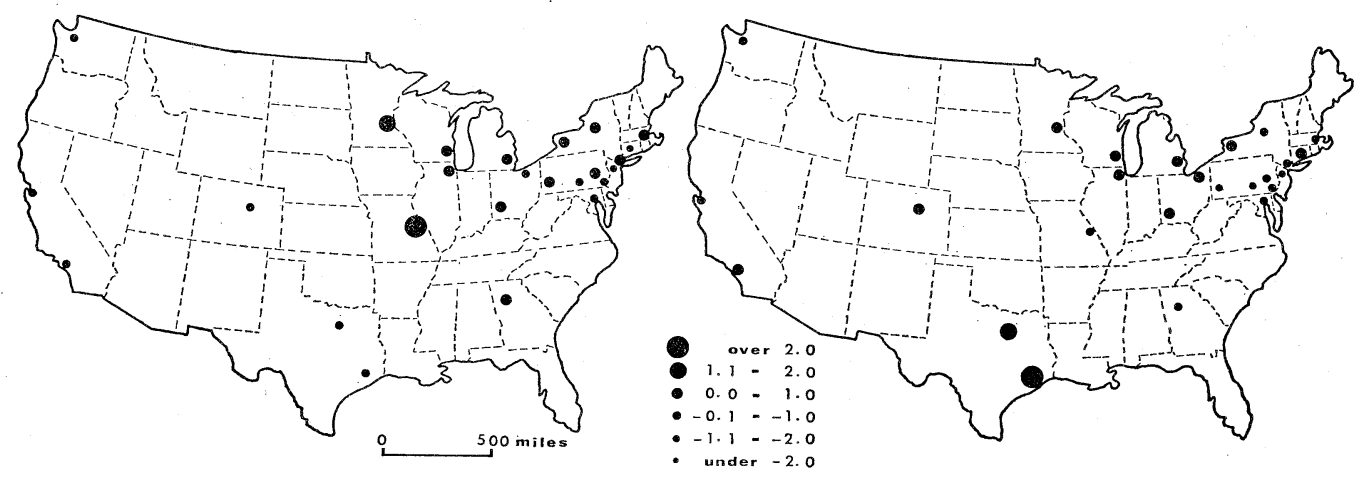

Fig. 8 Factor scores on factor 7

Fig. 9 Factor scores on factor 8

\section{Commodity flow patterns}

The data on commodity flows which are expressed in the form of $25 \times 25$ origin/destination flow matrix are used as an indicator of the basic structure of commodity flows. The $25 \times 25$ table summarizes total flows of the commodities between production areas, by quantity. The matrix is subjected to R-mode factor analysis in which the column correlation matrix is factored, yielding factor loadings showing groups of destinations, or consuming regions. The derived factor scores indicate the most prominent sources of shipments to each group.

The factor analysis, with Varimax rotation, extracted six factors, or six consuming regions $^{6}$. Table 3 shows factor loadings. These six consuming regions together account for 80 per cent of the spatial pattern of commodity flows. The first consuming region, accounting for 25 per cent of the toal variance, is characterized by significant loadings of variables 1 (Boston), 2 (Hartford), 3 (New York), 4 (Newark-Jersey City), and 21 (Houston). Spatially, the variables except the variable 21 are concentrated in New England and New York-New Jersey areas. Empirically, this consuming region may be labled as the northern Megalopolis region, though the Houston area is included in the consuming region because of its high factor loading. The Houston area's high factor loading is explained later. Factor scores for this dimension reveal the prominent sources of shipments to this region. Figure 10 shows spatial linkages between prominent shipment places and consuming places ${ }^{7}$. The first consuming region is characterized by the predominance of Houston as an important shipper. The areas within this region is strongly served by Houston. That means, empirically, that Houston supplies a great quantity of petroleum to this consuming region. About 40 per cent of petroleum shipments from Houston is directed toward the northern Megalopolis, and the Houston area per se consumes a quantity of petroleum. As the northern Megalopolis and the Houston areas receive one main commodity, specifically petroleum, from the same shipper (Houston), these areas have the high factor loadings and are classified as the consuming region $\mathrm{I}$.

Consuming region II, accounting for 19 per cent of the total variance, is positively correlated with variables 11 (Cleveland), 12 (Pittsburgh), and 14 (Cincinnati). This may be called the Pittsburgh-Cleveland district. Figure 10 shows that Cleveland and 
Table 3 Factor loadings (Varimax rotation)

\begin{tabular}{|c|c|c|c|c|c|c|}
\hline \multirow{2}{*}{ Variables (areas) } & \multicolumn{6}{|c|}{ Factors } \\
\hline & I & II & III & IV & $\mathrm{V}$ & VI \\
\hline 1. Boston & $(-0.97)$ & -0.01 & 0.05 & -0.01 & 0.03 & -0.06 \\
\hline 2. Hartford & $(-0.98)$ & -0.02 & 0.05 & 0.00 & 0.01 & -0.05 \\
\hline 3. New York & $(-0.95)$ & -0.02 & 0.06 & -0.01 & -0.13 & 0.02 \\
\hline 4. Newark & $(-0.98)$ & 0.04 & 0.04 & -0.01 & -0.14 & -0.02 \\
\hline 5. Philadelphia & $(-0.74)$ & -0.08 & 0.05 & 0.02 & $(-0.54)$ & 0.08 \\
\hline 6. Baltimore & -0.06 & 0.26 & -0.02 & -0.16 & $(-0.91)$ & 0.17 \\
\hline 7. Allentown & 0.00 & 0.03 & 0.08 & -0.09 & $(-0.89)$ & 0.28 \\
\hline 8. Harrisburg & 0.16 & 0.09 & 0.07 & -0.08 & $(-0.84)$ & -0.19 \\
\hline 9. Syracuse & -0.35 & 0.00 & 0.16 & -0.12 & $(-0.62)$ & $(0.58)$ \\
\hline 10. Buffalo & 0.01 & 0.34 & 0.16 & -0.13 & -0.29 & $(0.61)$ \\
\hline 11. Cleveland & 0.03 & $(0.87)$ & 0.01 & -0.06 & -0.09 & 0.19 \\
\hline 12. Pittsburgh & -0.10 & $(0.90)$ & 0.03 & -0.07 & -0.22 & 0.07 \\
\hline 13. Detroit & 0.06 & 0.44 & -0.16 & -0.03 & 0.04 & $(0.70)$ \\
\hline 14. Cincinnati & -0.03 & $(0.84)$ & -0.21 & -0.02 & 0.02 & 0.21 \\
\hline 15. Chicago & -0.03 & 0.12 & $(-0.94)$ & -0.01 & -0.04 & 0.16 \\
\hline 16. Milwaukee & 0.07 & 0.10 & $(-0.94)$ & -0.02 & -0.03 & 0.10 \\
\hline 17. Minneapolis & 0.03 & -0.01 & $(-0.79)$ & -0.13 & 0.09 & -0.04 \\
\hline 18. St. Louis & $(-0.57)$ & 0.04 & -0.34 & -0.08 & 0.21 & 0.01 \\
\hline 19. Atlanta & 0.15 & 0.11 & -0.28 & -0.07 & -0.06 & $(0.77)$ \\
\hline 20. Dallas & $(-0.53)$ & -0.02 & -0.23 & -0.00 & 0.24 & 0.07 \\
\hline 21. Houston & $(-0.96)$ & 0.16 & -0.04 & 0.01 & 0.07 & -0.12 \\
\hline 22. Denver & -0.28 & -0.08 & $(-0.75)$ & 0.33 & 0.27 & 0.01 \\
\hline 23. Seattle & 0.15 & -0.08 & 0.05 & $(0.83)$ & 0.12 & -0.14 \\
\hline 24. San Francisco & 0.10 & -0.03 & 0.01 & $(0.92)$ & 0.07 & -0.06 \\
\hline 25. Los Angeles & -0.16 & -0.04 & -0.03 & $(0.78)$ & 0.08 & 0.01 \\
\hline Eigenvalues & 6.27 & 4.82 & 3.82 & 2.09 & 1.93 & 1.21 \\
\hline $\begin{array}{l}\text { Cumulative } \\
\text { proportion of } \\
\text { total variance }\end{array}$ & $25 \%$ & $44 \%$ & $60 \%$ & $68 \%$ & $.76 \%$ & $80 \%$ \\
\hline
\end{tabular}

Loadings greater than an absolute value of 0.50 are shown in parentheses.

Factors with eigenvalue greater than 1.0 are rotated.

Pittsburgh serve as both a receiver and a shipper, but Cincinnati is a receiver, or consumer. Detroit plays a great role in shipping commodities to this region. This region is the continent's outstanding producer of iron and steel, and within this region millions of tons of iron ore, limestone, and coal move. Detroit supplies petroleum and machinery to this region. Cincinnati receives metal stampings from this region.

Consuming region III, accounting for 16 per cent of the total variance, consists of Chicago, Minneapolis-St. Paul, and St. Louis (Table 3). Chicago serves both as a receiver and a shipper. St. Louis and Minneapolis-St. Paul are prominent shippers to this region (Fig. 11). The main commodity from Chicago to Milwaukee, Minneapolis-St. Paul, and Denver may be machinery. Minneapolis-St. Paul supplies foods to this region.

Consuming region IV, accounting for 8 per cent of the total variance, consists of three Pacific Coast urban areas, namely, Los Angeles, San Francisco, and Seattle areas (Table 3). This region is characterized by mutual interdependency (Fig. 10). Three areas are both 


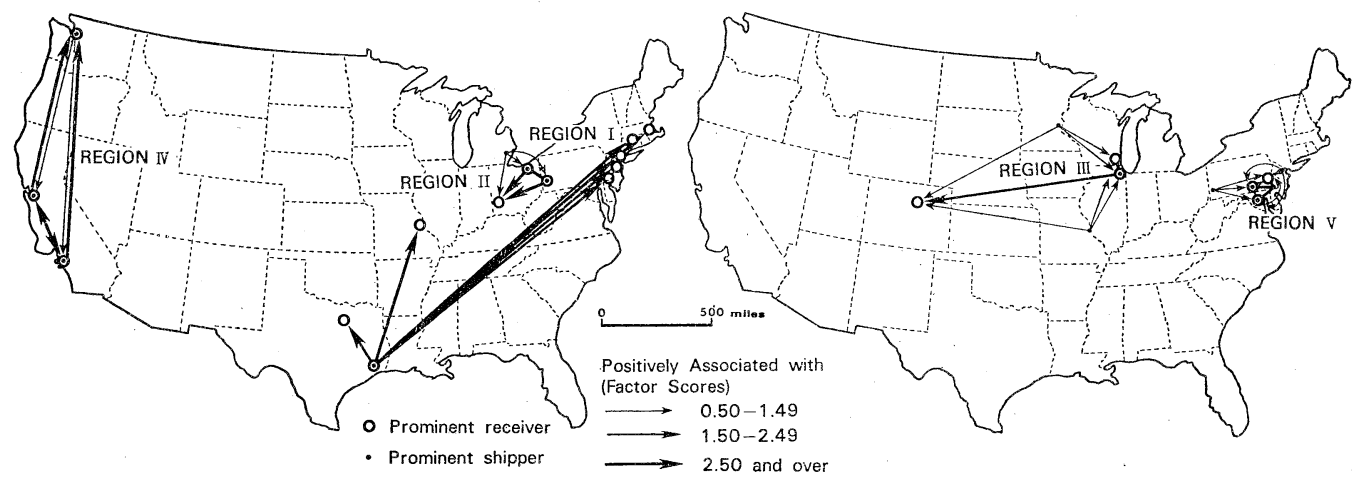

Fig. 10 Consuming regions, I, II and IV

Fig. 11 Consuming regions, III and V

a shipper and a receiver, though the degree to which Seattle contributes is less than Los Angeles and San Francisco do.

Consuming region $\mathrm{V}$, accounting for 8 per cent of the total variance, consists of four southern Megalopolis areas, and the Syracuse-Rome areas (Table 3). Major shippers to this region are Philadelphia and Pittsburgh (Fig. 11). Philadelphia, Harrisburg, and Baltimore are both a shipper and a receiver. Pittsburgh and Newark-Jersey City are shippers outside this region.

Consuming region VI, accounting for 4 per cent of the total variance, is not spatially compact (Fig. 12). This region includes Detroit, Buffalo, Atlanta, and Syracuse-Rome areas. Buffalo and the Syracuse-Rome areas are receivers, but Detroit and Atlanta are both a shipper and a receiver. Detroit plays a major role in shipments, though Newark and Philadelphia ship commodities to this region. Detroit provides Syracuse-Rome, Buffalo, and the Atlanta areas with metal stampings and machinery parts. Atlanta provides Buffalo and Detroit with pulp and paper products.

From these commodity flow patterns, it can be said that consuming regions are to some extent fromed by neighboring areas. This may support gravity models of commodity flows. However, some consuming regions are served by distant areas which ship certain

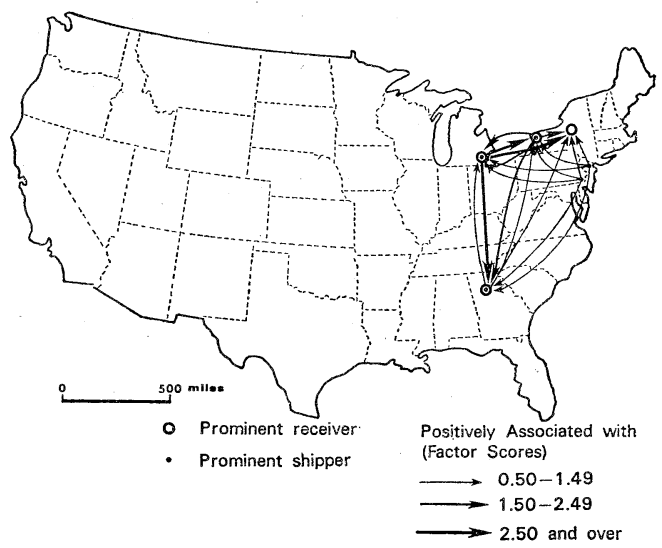

Fig. 12 Consuming region VI 
types of commodities. This indicates a good example of complementarity. Houston plays a great role in forming the northern Megalopolis consuming region.

\section{Producing regions}

How do consuming regions differ from producing regions? If a consuming region, as determined by commodity flow patterns, is similar to a producing region, which can be revealed by commodity flows, there them exists a functional region in which areas are mutually interdependent.

The $25 \times 25$ matrix of commodity flows is then subjected to Q-mode factor analysis, yielding factor loadings showing origins, or producing regions, and factor scores showing dominant receivers for each producing region. Table 4 shows the factor loadings. The Q-mode factor analysis, with Varimax rotation, extracted seven producing regions ${ }^{8}$. These seven producing regions together account for 74 per cent of the spatial variation of commodity flows. The first producing region, accounting for 26 per cent of the total variance, is characterized by significant loadings of such areas as Boston, Hartford, New York, Newark, Syracuse-Rome, and Houston. This region may be labled as New EnglandNew York region. Within this region, Boston, Hartford, New York, and Newark-Jersey City are dominant receivers (Fig. 13). A prominent receiver outside the region is Buffalo. Commodities are shipped among areas within the region.

Producing region II, accounting for 14 per cent of the total variance, consists of the southern Great Lakes urban area (Table 4). All areas within this region are both a shipper and a receiver. In other words, this region is functionally organized. Chicago is a main receiver from this region (Fig. 14). This region is characterized by iron and steel, and machinery and metal fabrication industries. These commodities are carried by various modes of transportation.

Producing region III, accounting for 10 per cent of the total variance, consists of Denver, San Francisco, and Los Angeles areas (Table 4). However, interestingly enough, a prominent receiver from this region is New York (Fig. 14). Empirically, this flow pattern can be interpreted as movements of agricultural products from the region to New York, a major market place.

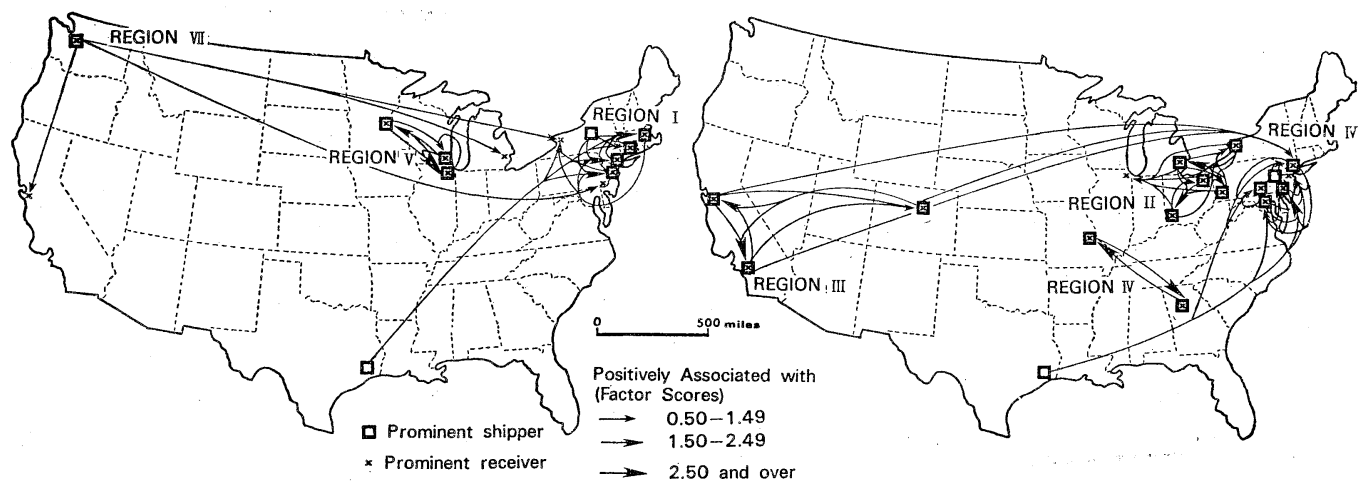

Fig. 13 Producing regions, I, V and VII Fig. $14 \quad$ Producing regions, II, III, IV and VI 
Table 4 Factor loadings (Varimax rotation)

\begin{tabular}{|c|c|c|c|c|c|c|c|}
\hline \multirow[b]{2}{*}{ Variables (areas) } & \multicolumn{7}{|c|}{ Factors } \\
\hline & I & II & III & IV & $\mathrm{V}$ & $V I$ & VII \\
\hline 1. Boston & $.79)$ & 0.10 & -0.11 & 0.14 & 0.01 & 0.13 & 0.06 \\
\hline 2. Hartford & $(0.95)$ & -0.01 & -0.01 & -0.18 & 0.10 & -0.04 & -0.01 \\
\hline 3. New York & $(0.74)$ & -0.14 & 0.07 & $(-0.56)$ & 0.01 & -0.02 & -0.05 \\
\hline 4. Newark & $(0.74)$ & -0.07 & 0.04 & -0.43 & -0.06 & -0.06 & -0.06 \\
\hline 5. Philadelphia & 0.09 & -0.04 & -0.01 & $(-0.87)$ & -0.04 & -0.00 & -0.11 \\
\hline 6. Baltimore & 0.31 & -0.00 & -0.16 & $(-0.87)$ & -0.04 & 0.11 & 0.00 \\
\hline 7. Allentown & 0.40 & -0.03 & -0.00 & $(-0.89)$ & -0.09 & -0.02 & 0.03 \\
\hline 8. Harrisburg & 0.01 & 0.03 & -0.19 & $(-0.86)$ & -0.01 & 0.16 & 0.02 \\
\hline 9. Syracuse & $(0.83)$ & -0.13 & -0.18 & -0.14 & -0.01 & 0.13 & 0.07 \\
\hline 10. Buffalo & 0.31 & $(-0.68)$ & -0.16 & -0.13 & 0.03 & 0.11 & 0.14 \\
\hline 11. Cleveland & -0.08 & $(-0.84)$ & -0.09 & 0.04 & -0.06 & 0.13 & -0.06 \\
\hline 12. Pittsburgh & -0.05 & $(-0.76)$ & -0.13 & -0.12 & -0.03 & 0.15 & -0.20 \\
\hline 13. Detroit & -0 & $(-$ & -0.01 & 0.03 & 0.21 & -0.10 & 0.15 \\
\hline 14. Cincinnati & 0 & $(-0.68)$ & 0.01 & 0.07 & 0.16 & -0.17 & -0.00 \\
\hline 15. Chícago & 0.0 & -0.22 & 0.07 & 5 & 9) & -0.13 & -0.02 \\
\hline 16. Milwaukee & .11 & 0 & 1 & - & & -0.11 & -0.01 \\
\hline 17. Minneapolis & -0 & 2 & -0.19 & 0.11 & 8) & 0.15 & 0.03 \\
\hline 18. St. Louis & -0.06 & 0.07 & -0.05 & 0.10 & 0.25 & $(-0.68)$ & -0.05 \\
\hline 19. Atlanta & -0.04 & -0.00 & -0.11 & 0.06 & -0.15 & $(-0.82)$ & -0.02 \\
\hline 20. Dallas & -0.18 & 0.16 & 0.08 & 0.12 & -0.11 & 0.04 & $(-0.65)$ \\
\hline 21. Houston & $(0.73)$ & 0.10 & 0.10 & $(-0.52)$ & -0.11 & -0.05 & -0.09 \\
\hline 22. Denver & 01 & 0.12 & $(0.90)$ & 0.09 & 0.12 & 0.02 & -0.15 \\
\hline 23. Seattle & -0.15 & 0.14 & 0.15 & -0.00 & -0.10 & 0.09 & $(0.73)$ \\
\hline 24. San Francisco & -0.14 & 0.14 & $(0.67)$ & 0.14 & -0.10 & 0.14 & 0.39 \\
\hline 25. Los Angeles & -0.06 & 0.07 & $(0.87)$ & 0.09 & -0.05 & 0.07 & 0.05 \\
\hline Eigenvalues. & 6.47 & 3.61 & 2.36 & 2.02 & 1.66 & 1.29 & 1.14 \\
\hline $\begin{array}{l}\text { Cumulative } \\
\text { proportion of } \\
\text { total variance }\end{array}$ & $26 \%$ & $40 \%$ & $50 \%$ & $58 \%$ & $64 \%$ & $70 \%$ & 174 \\
\hline
\end{tabular}

Loadings greater than an absolute value of 0.50 are shown in parentheses. Factors greater than 1.0 are rotated.

Producing region IV, accounting for 8 per cent of the total variance, includes New York, Philadelphia, Harrisburg, Baltimore, Allentown, and Houston (Table 4). Like the New England-New York producing region, this region also includes Houston. Prominent receivers are New York, Philadelphia, Baltimore, and Harrisburg, which are within the region (Fig. 14).

Producing region V, accounting for 8 per cent of the total variance, consists of Chicago, Milwaukee, and Minneapolis-St. Paul, which are close to each other (Table 4). They are both a shipper and a receiver (Fig. 13). Thus, this region is said to be functionally united.

Producing region VI, accounting for 6 per cent of the total variance, includes two areas, St. Louis and Atlanta (Table 4). Both areas are interdependent (Fig. 14).

Commodity flow patterns in the producing region VII show interesting linkages. The producing region consists of only one area, Seattle (Table 4). However, commodities are 
shipped to San Francisco, Detroit, Philadelphia, and Buffalo areas (Fig. 13). Therefore, main commodities shipped may be lumber, and pulp and paper products.

With respect to commodity flows, six consuming and seven producing regions are identified. A few consuming and producing regions tend to be formed by neighboring urban areas. The consuming regions II, III, IV, and V, and the producing regions II and V consist of neighboring metropolitan areas. The consuming region II is, in areal extent, similar to the producing region II. Therefore, it can be said that these regions are intergrated into one functional region in which urban areas are interdependent. In other words, this functional region is a relatively independent region. Other consuming and producing regions show intricate linkages in their commodity flows. These flows between distant places, however, can be explained by the movements of foods and other bulky products, such as petroleum, lumber, and pulp and paper products.

\section{Canonical analysis}

Eight socio-economic dimensions of the production areas, six consuming and seven producing regions were identified. By using the prodcedure of canonical correlation ${ }^{9)}$, the relationships between two sets of data can be determined.

To determine relationships between socio-economic dimensions and commodity flows to the consuming regions, fourteen variables were employed. These variable are divided into two groups, consuming regions $\left(X_{1}-X_{6}\right)$ and socio-economic dimensions $\left(Y_{1}-Y_{8}\right)$. These input variables are factor scores derived from the factor analysis.

The results of the canonical analysis of relationships between socio-economic dimensions and commodity flows to consuming regions are summarized in Table $5^{10)}$. The first three canonical correlations are highly significant by the chi-square test; the remaining three vectors are of lesser significance. The canonical coefficients in each pair of vectors define a pattern of association between the predominant socio-economic dimensions of each region, and their role as the major shippers of commodities to consuming regions. The strength and sign of canonical coefficients can be used to indicate which of the original variables are to be considered, and the direction of their association ${ }^{11}$.

An examination of the coefficients of canonical vectors in Table 6 shows that they have empirical significance. The first pair of vectors reveal that increases in commodity flows to $X_{5}$ (southern Megalopolis region) are associated with commodity flows from metropolitan areas of high population density per dwelling unit and high urban growth rate through manufacturing. The Philadelphia-Wilmington-Trenton region which has a high population density per dwelling unit and a high urban growth rate through manufacturing is a main shipper to the southern Megalopolis region. It can be said that the southern Megalopolis region attracts commodities, and the demand for goods stimulates manufacturing activities, which accelerate urban growth.

Canonical vector II shows that decreases in commodity flows to $X_{4}$ (Pacific Coast region) are associated with commodity flows from metropolitan areas of high unemployment rates. This indicates that Los Angeles, San Francisco, and Seattle areas are shippers, which have high unemployment rates, however commodity flows to this region are decreasing. For 
Table 5 Canonical analysis of relationships between socio-economic dimensions and commodity flows to consuming regions

\begin{tabular}{|c|c|c|c|c|c|c|c|}
\hline & \multicolumn{7}{|c|}{ Canonical Vectors } \\
\hline & & I & II & III & IV & $\mathrm{V}$ & VI \\
\hline \multirow{6}{*}{$\begin{array}{l}\text { Consuming } \\
\text { regions }\end{array}$} & $\mathrm{x}_{1}$ & 0.356 & -0.091 & -0.502 & 0.744 & -0.237 & -0.056 \\
\hline & $x_{2}$ & 0.244 & 0.443 & 0.071 & -0.281 & -0.791 & -0.183 \\
\hline & $\mathrm{x}_{3}$ & 0.143 & -0.255 & 0.607 & 0.265 & 0.021 & -0.690 \\
\hline & $x_{4}$ & -0.105 & 0.788 & 0.305 & 0.441 & 0.249 & 0.133 \\
\hline & $\mathrm{x}_{5}$ & -0.855 & 0.036 & -0.248 & 0.143 & -0.233 & -0.361 \\
\hline & $\mathrm{x}_{6}$ & 0.226 & 0.328 & -0.468 & -0.285 & 0.448 & -0.584 \\
\hline \multirow{8}{*}{$\begin{array}{l}\text { Socio-economic } \\
\text { dimensions }\end{array}$} & $\mathrm{Y}_{1}$ & -0.010 & -0.320 & 0.139 & -0.011 & -0.280 & -0.295 \\
\hline & $\mathrm{Y}_{2}$ & -0.123 & -0.216 & 0.044 & 0.412 & -0.101 & -0.689 \\
\hline & $\mathrm{Y}_{3}$ & -0.338 & -0.254 & 0.256 & 0.492 & 0.449 & 0.055 \\
\hline & $\mathrm{Y}_{4}$ & -0.013 & 0.174 & -0.745 & 0.235 & 0.468 & -0.092 \\
\hline & $\mathrm{Y}_{5}$ & 0.655 & -0.064 & 0.030 & -0.273 & 0.334 & -0.479 \\
\hline & $\mathrm{Y}_{6}$ & -0.003 & -0.856 & -0.257 & -0.271 & 0.137 & 0.243 \\
\hline & $Y_{7}$ & -0.266 & -0.027 & -0.524 & -0.092 & -0.494 & -0.201 \\
\hline & $\mathrm{Y}_{8}$ & -0.608 & 0.134 & 0.126 & -0.613 & 0.341 & -0.313 \\
\hline $\begin{array}{l}\text { Canonical } \\
\text { correlation }\end{array}$ & & 0.901 & 0.852 & 0.814 & 0.765 & 0.582 & 0.217 \\
\hline Chi-square & & $94.42 \% *$ & $65.17 * *$ & $42.51 *$ & 23.52 & 8.09 & 0.85 \\
\hline $\begin{array}{l}\text { Degree of } \\
\text { freedom }\end{array}$ & & 48 & 35 & 24 & 15 & 8 & 3 \\
\hline
\end{tabular}

\footnotetext{
** Significant at the 0.01 level of confidence.

* Significant at the 0.05 level of confidence.

$\mathrm{X}_{1}$ : Northern Megalopolis region. $\mathrm{X}_{2}$ : Pittsburgh-Cleveland region. $\mathrm{X}_{3}$ : Chicago-Milwaukee region. $\mathrm{X}_{4}$ : Pacific Coast region. $\mathrm{X}_{5}$ : Southern Megalopolis region. $\mathrm{X}_{6}$ : Detroit-Buffalo-Atlanta region. $\mathrm{Y}_{1}$ : Urban size. $\mathrm{Y}_{2}$ : Negro population. $\mathrm{Y}_{3}$ : Service activities. $\mathrm{Y}_{4}:$ Family income. $\mathrm{Y}_{5}$ : Population density per dwelling unit. $\mathrm{Y}_{6}:$ Employment. $\mathrm{Y}_{7}:$ Family size. $\mathrm{Y}_{8}:$ Urban growth.
}

canonical vector III, increases in commodity flows to $X_{1}$ (northern Megalopolis region) and decreases in commodity flows to $X_{3}$ (Chicago-Milwaukee region) are associated with commodity flows from areas of low family income and small family size. Houston-Galveston areas as a main shipper to the northern Megalopolis region has a low family income and a small family size.

In the second canonical analysis, the seven producing regions and the eight socio-econo mic dimensions formed five pairs of canonical vectors with significant correlations (Table 
6). Canonical vector I reveals that commodity flows from producing region $X_{3}$ (Pacific Coast region) and $X_{7}$ (Seattle region) are associated with commodty flows to regions of low unemployment rates. This relationship is illustrated in Figures 13 and 14, in which commodities produced in the Pacific Coast region are shipped to New York, Philadelphia, Buffalo, and Detroit where unemployment rates are relatively low. Canonical vector II shows that commodity flows from producing region $X_{1}$ (New England-New York region) are associated with commodity flows to large metropolitan areas. Figure 13 illustrates this pattern. Commodities from the producing region $\mathrm{I}$ are directed to the northern Megalopolis region, which consists of four large metropolitan areas.

Canonical vector III shows that commodity flows from producing region $X_{2}$ (southern

Table 6 Canonical analysis of relationships between socio-economic dimensions and commodity flows from producing regions

\begin{tabular}{|c|c|c|c|c|c|c|c|}
\hline & \multicolumn{7}{|c|}{ Canonical Vectors } \\
\hline & I & II & III & IV & $\mathrm{V}$ & VI & VII \\
\hline \multirow{7}{*}{$\begin{array}{l}\text { Producing } \\
\text { regions }\end{array}$} & $x_{1} \quad-0.291$ & -0.670 & -0.449 & -0.302 & -0.149 & 0.217 & 0.324 \\
\hline & 0.277 & 0.266 & -0.648 & -0.154 & 0.217 & 0.425 & -0.426 \\
\hline & $X_{3} \quad-0.560$ & 0.054 & -0.005 & -0.309 & 0.682 & -0.306 & -0.169 \\
\hline & 0.094 & 0.511 & 0.012 & -0.690 & -0.184 & -0.052 & 0.466 \\
\hline & $\begin{array}{ll}x_{5} & -0.008\end{array}$ & -0.231 & 0.378 & -0.513 & -0.346 & 0.071 & -0.645 \\
\hline & $x_{6} \quad-0.335$ & 0.224 & -0.456 & 0.138 & -0.528 & -0.529 & -0.228 \\
\hline & $x_{7} \quad-0.636$ & 0.335 & 0.166 & 0.175 & -0.183 & 0.626 & 0.013 \\
\hline \multirow{8}{*}{$\begin{array}{l}\text { Socio-economic } \\
\text { dimensions }\end{array}$} & 0.468 & 0.702 & 0.082 & 0.369 & -0.241 & 0.165 & -0.244 \\
\hline & $Y_{2}-0.325$ & 0.252 & -0.529 & -0.230 & -0.665 & 0.013 & 0.237 \\
\hline & $\mathrm{Y}_{3} \quad-0.029$ & 0.169 & -0.518 & -0.125 & 0.502 & 0.492 & -0.137 \\
\hline & $Y_{4} \quad-0.284$ & -0.072 & 0.349 & -0.357 & -0.282 & 0.313 & -0.694 \\
\hline & $\mathrm{Y}_{5}-0.182$ & -0.301 & 0.119 & 0.619 & -0.280 & 0.191 & 0.112 \\
\hline & 0.666 & -0.545 & -0.349 & -0.090 & -0.285 & 0.117 & -0.180 \\
\hline & 0.269 & 0.061 & 0.430 & -0.422 & -0.089 & 0.443 & 0.572 \\
\hline & 0.213 & 0.137 & 0.053 & -0.313 & -0.026 & -0.621 & -0.110 \\
\hline $\begin{array}{l}\text { Canonical } \\
\text { correlation }\end{array}$ & 0.971 & 0.925 & 0.866 & 0.835 & 0.691 & 0.623 & 0.184 \\
\hline Chi-square & $145.42 \% *$ & $96.92 * *$ & $63.94 * *$ & $40.33 * *$ & $19.98 *$ & 8.93 & 0.59 \\
\hline $\begin{array}{l}\text { Degree of } \\
\text { freedom }\end{array}$ & 56 & 42 & 30 & 20 & 12 & 6 & 2 \\
\hline
\end{tabular}

** Significant at the 0.01 level of confidence.

* Significant at the 0.10 level of confidence.

$\mathrm{X}_{1}$ : New England-New York region. $\mathrm{X}_{2}$ : Southern Great Lakes region. $\mathrm{X}_{3}:$ Pacific Coast region. $\mathrm{X}_{4}$ : Southern Megalopolis region. $\mathrm{X}_{5}$ : Chicago-Milwaukee-Minneapolis region. $\mathrm{X}_{6}:$ St. Louis-Atlanta region. $\mathrm{X}_{7}$ : Seattle region. $\mathrm{Y}_{1}$ : Urban size. $\mathrm{Y}_{2}$ : Negro population. $\mathrm{Y}_{3}$ : Service activities. $\mathrm{Y}_{4}$ : Family income. $Y_{5}$ : Population density per dwelling unit. $Y_{6}:$ Employment. $Y_{7}:$ Family size. $Y_{8}$ : Urban growth. 
Great Lakes region) are associated with commodity flows to regions in which Negro populations are concentrated and service activities are less concentrated. This relationship is shown in Fig. 14. The metropolitan areas forming the producing region II are both shippers and receivers, and these areas along with Chicago area have high Negro population rates and relatively fewer service activities. Canonical vector IV reveals that commodity flows from producing region $X_{4}$ (southern Megalopolis region) are associated with commodity flows to metropolitan areas of high population density per dwelling unit. Main receivers from this region are the Philadelphia, Baltimore, New York, and Harrisburg regions whose population densities are high. Canonical vector $\mathrm{V}$ shows two associations. One is that commodity flows from producing region $X_{6}$ (St. Louis-Atlanta region) are associated with relatively high Negro population rates. In this region, St. Louis and Atlanta have high Negro population rates. The other is that commodity flows from producing region $X_{3}$ (Pacific Coast region) are associated with commodity flows to areas of many service activities.

The results of the two canonical analyses suggest that some consuming or producing regions are interdependent with certain socio-economic dimensions. The significant associations, however, do not clearly support the expectations that commodity flow patterns are formed among dissimilar regions, in terms of socio-economic characteristics. For example, the first canonical analysis reveals that consuming region V (Fig. 11) is assoicated with commodity flows from metropolitan areas of high population density and high urban growth rate, and that consuming region IV (Fig.10) is associated with commodity flows from metropolitan areas of high unemployment rates. But the main shippers to the consuming region $\mathrm{V}$ are neighboring metropolitan areas and metropolitan areas in the region. The consuming region IV consists of three metropolitan areas, which are both shippers and receivers. Therefore, the consuming regions, IV and V, may consist of neighboring metropolitan areas rather than metropolitan areas of different socio-economic characteristics. The different association is found in consuming region I (Fig. 10), whose main shipper is the HoustonGalveston area which is characterized by low family income and small family size. It may be appropriate to interpret that the consuming region $I$ is associated with the HoustonGalveston area by its demands of petroleum rather than by dissimilar socio-economic characteristics.

The second canonical analysis, however, shows different associations between producing regions and socio-economic diemensions. Six producing regions are related to certain socio-economic characteristics of metropolitan areas, to which each producing region ship commodities. Producing regions III and VI (Fig. 14) ship commodities to the areas of low unemployment rates in the Northeast. Furthermore, producing regions I (Fig. 13) and IV (Fig. 14) are characterized by internal circulation of commodity flows within the regions. And these regions are associated with the urban size dimension and the high population density dimension. The northeastern urban manufacturing core, or Megalopolis, affects some aspects of its own socio-economic dimensions, and vice versa. This agglomeration of population and economic activities in the Northeast not only ships a 
large quantity of commodities to metropolitan areas within the region but also receives quantities of commodities produced both within and outside the region.

Producing regions, II (Fig. 14) and VI (Fig. 14), are associated with commodity flows to the areas of high Negro population rates. Although the producing region II ships commodities to the Chicago area, these flow patterns show internal circulation of commodity flows. The flow pattern of producing region VI shows internal circulation of commodities.

The canonical analyses indicate that, in general, commodities are moved toward areas of large urban size and high population densities. And some consuming regions and producing regions are characterized by internal circulation of commodity flows within the region, though they are associated with certain socio-economic dimensions.

\section{Conclusion}

Socio-economic dimensions of the selected metropolitan areas, and commodity flow patterns were identified by factor analysis. By canonical analysis, it was possible to estimate relationships between socio-economic dimensions of the metropolitan areas and commodity flow patterns.

There are some relationships among them: 1) High population density and high urban growth rate are associated with commodity flows to the southern Megalopolis, but the main shippers to this region are neighboring metropolitan areas; 2) High unemployment rates are associated with internal circulation of commodities within the Pacific Coast region; 3) Low family income and small family size are associated with commodities to the northern Megalopolis. Houston-Galveston area is the main shipper to this region; 4) Low unemployment rates are associated with commodity flows from the Pacific Coast region to some of metropolitan areas in the Northeast; 5) Large urban size and high population density are associated with internal circulation of commodities within New York-New England and southern Megalopolis region ; 6) High Negro population rates are associated with internal circulation of commodities within the Great Lakes region and St. LouisAtlanta region ; 7) Service activities are associated both with directional commodity flows from the San Francisco-Los Angeles region to the New York area and with internal circulation within the San Francisco-Los Angels region.

Although a consuming region or a producing region tends to be formed by neighboring metroppolitan areas, it can be said from these analyses that some aspects of socio-economic characteristics of metropolitan areas are associated with commodity flow patterns, and vice versa. Furthermore, the northeastern manufacturing core, or Megalopolis, is a hub of commodity flows in the United States, and it stimulates manufacturing activities not only in Megalopolis but also in other metropolitan areas.

Acknowledgements

The writer would like to express his gratitude to Drs. James O. Wheeler and James B. Kenyon, Department of Geography, University of Georgia, for their encouragement and review of the original manuscript, and to Dr. Shozo Yamamoto, Department of Geoscience, University of Tsukuba, for his encouragement. 


\section{Notes}

1) The tabulation of commodity flows were based on detailed information obatined from a sample of about 1.4 million shipping records drawn from the files of about 13,000 manufacturing establishments. However, all flows from nonmanufacturing activities, flows by pipeline, and commodity movements from ordinace, fluid milk, bakery products, manufactured ice, primary forest products, printing and publishing plants, and from plants with fewer than twenty employees are excluded. Although there are flow matrices for tons and ton-miles for numerous commodity classes for producction areas, only the total aggregated commodities, that is total flows in tons, are analyzed in this study. The data were then organized into a $25 \times 25$ commodity flow matrix where an individual cell contained the total flows from origin to a destination.

2) For the mathematics of factor analysis, see Harman, H. H. (1967) : Modern Factor Analysis. 2nd. ed. ; Chicago: University of Chicago Press, $474 \mathrm{p}$.

3) Greer-Wootten, B. (1972) : A Bibliography of Statistical Application in Geography. Commission on College Geography Technical Paper No. 9, Association of American Geographers, Washington D. C., p. 90.

4) Canonical analyses have also been used by Ray, D. M. (1971) : From Factorial Ecology to Canonical Ecology: The Spatial Interrelationship of Economic and Cultural Differences in Canada. Econ. Geog., 47, 344 355: Clark, D. (1973) : The Formal and Functional Structure of Wales. Ann. Assoc. Amer. Geogr., 63, 171 184; and Schwind, P. J. (1975) : A General Field Theory of Migration : United States, 1955 1960. Econ. Geog., 51, 1 16.

5) The computer program, "BMD-08M-Factor Analysis," developed by Health Science Computer Facility, UCLA, was run on the IBM 360/370 at the University of Georgia.

6) Ibid.

7) Although urban places are connected with major shippers by lines of different width based on factor scores, it should be recalled that factor scores indicate the degree of contribution to each consuming region. Therefore, the width of lines can not show an exact amount of movements of goods between two places. However, this figure shows clear spatial linkages, and it is easy to understand commodity flow patterns.

8) The computer program, "BMD-08M-Factor Analysis," developed by Health Science Computer Facility, UCLA, was run on the IBM 360/370 at the University of Georgia.

9) For the mathematical statements of the technique, see Cooley, W. W. and Lohnes, P. R. (1962) : Multivariate Procedures for the Behavioral Science. New York: John Wiley \& Sons, Inc., 211 p.

10) The computer program, CANON, written by P. Lohnes and modified by the Department of Geography, University of Iowa, and the author, was run on the IBM 360/370 at the University of Georgia.

11) Interpretation of the results of the canonical analysis must proceed with caution. As mentioned before, the input avariables are factor scores, and coefficients of canonical vectors reflect the direction of original variables. For example, the first socio-economic dimension and the first consuming region were identified by high negative factor scores. Thus, the negative coefficent of canonical vector I for socio-economic dimension $\mathrm{Y}_{1}$ means the positive relation to the consuming regions, though its strength of the association is very weak.

\section{References}

Berry, B. J. L. (1966) : Interdependency of flows and spatial structure : A general field theory formulation, in Essays on Commodity Flows and the Spatial Structure of the Indian Economy. Univ. of Chicago, Dept. of Geography Res. Pap. 111, 189 256.

Clark, D. (1973) : The formal and functional structure of Wales. Ann. Assoc. Amer. Geogr., 63, $171 \sim 184$. Cole, J. P. and King, C. A. M. (1968) : Quantitative Geography. London : John Wiley \& Sons, Inc., 692 p. Cooley, W. W. and Lohnes, P. R. (1962) : Multivariate Procedures for the Behavioral Science. New York : John Wiley \& Sons, Inc., 211 p. 
Gauthier, H. L. (1968): Transportation and the growth of the Sao Paulo economy. Journal of Regional Science, 8, $77 \sim 94$.

Greer-Wootten, B. (1972) : A Bibliography of Statistical Application in Geography. Commission on College Geography Technical Paper No. 9, Association of American Geographers, Washington, D. C., 91 p.

Harman, H. H. (1967) : Modern Factor Analysis. 2nd. ed., Chicago : Univ. of Chicago Press, 474 p.

Janson, C-G. (1971) : A Preliminary report on Swedish urban spatial structure. Econ. Geog., 47, $249 \sim 257$.

King, L. J. (1966) : Cross-Sectional analysis of canadian urban dimensions : 1951 and 1961. The Canadian Geographer, 10, 205 224.

McConnell, J. E. (1967) : The Middle East : Competitive or complementary ? Tijdschrift Voor Economische en Sociale Geografie, 58, 82 93.

Murdie, R. A. (1969) : The Factorial Ecology of Metropolitan Toronto : 1951 and 1961. Univ. of Chicago, Dept of Geography Res. Pap. 116, 212 p.

Ray, D. M. (1971) : From factorial ecology to canonical ecology: The spatial interrelationship of economic and cultural differences in Canada. Econ. Geog., 47, 344 355.

Schwind, P. J. (1975) : A general field theory of migration: United States, 1955 1960. Econ. Geog., 51, $1 \sim 16$.

Smith, R. H. T. (1970) : Concepts and methods in commodity flow analysis. Econ. Geog., 46, 404 416.

Taaffe, E. J. and Gauthier, H. L. (1973) : Geography of Transportation. Englewood Cliffs, N. J. : PrenticeHall, $226 \mathrm{p}$.

Bureau of the Census (1970) : Census of Transportation, 1967, Vol. III. Washington, D. C. : U. S. Department of Commerce, Bureau of the Census.

Bureau of the Census (1972) : County and City Data Book. Washington, D. C. : U. S. Department of Commerce, Bureau of the Census.

(Received Sep. 16, 1975 ; accepted Dec. 13, 1975) 


\section{アメリカ合衆国主要大都市地域における物資流動と 社会・経済構造の正準相関分析}

\section{菅 野 峰 明*}

物資の流動パターンは地域の社会・経済活動に関係しており，地域の特徴が誘因となって物資の流動が生じ， また逆に，その流動が原因となって地域の特徵をさらに変化させる. しかし，物資の流動パターンはどのよう な社会・経済的特性と関連しているかについては十分に明らかになっているとはいい難い.

本論では，アメリカ合衆国の主要な大都市地域間の物資流動パターンとそれらの地域の社会・経済構造の関 係を明らかにするため，43 の社会・経済的変数と 25 の大都市地域間の物資流動（OD 行列）にそれぞれ因子 分析を適用して，8つの社会・経済的因子，6つの消費地域（着地域群）, 7 つ生産地域（発地域群）を抽出 し，これらの社会・経済的因子と消費地域・生産地域との関係を正準相関分析によって考察した.

$8 つ の$ 社会・経済的因子と 6 つの消費地域との関係の中では，統計的に 3 つの関係が有意であった．それら の関係はそれぞれ次のことを示唆している，すなわち，(1)アメリカ合衆国北東部メ分ロポリス南部への物資の 供給は, 人口密度・都市成長率の高い大都市地域加行なわれている. しかし, これらの供給地は消費地域自 体かあるいはその周辺の大都市地域である. (2)太平洋岸の消費地域への物資の供給は, この消費地域内部で相 互に行なわれて抢り，さらに，この消費地域は失業率が比較的高いのが特徴である. (3)アメリカ合衆国北東部 メガロポリス北部への物資の供給は，低所得・家族規模の小さい大都市地域から行なわれている．これは石油 を供給するヒューストン地域の影響が大きい.

8 つの社会・経済的因子と 7 つ生産地域との関係の中では, 統計的に 5 つの関係が有意であった。それら の関係はそれぞれ次のことを示唆している.すなわち，1太平洋岸生産地域からの物資は失業率の比較的低い 大都市地域（アメリカ合衆国北東部）に向かう。(2)アメリカ合衆国北東部生産地域からの物資は規模の大きな 大都市地域（アメリカ合圌国北東部）に向かう。(3)五大湖南部生産地域からの物資は黒人人口率が高く，その 上サービス業の比較的少ない大都市地域に向かう. (4アメリカ合衆国北東部メ分ロポリス南部の生産地域から の物資は居住密度の高い大都市地域に向かう。 (5)サンフランシスコ・ロスアンジェルスからの物資はサービス 業の多い大都市地域に向かう.

以上のことから，消費地域・生産地域はともに近接した大都市地域から形成される傾向にあるが，ある地域 の社会・経淯的特性の違いによって，物資の流動パターンが形成されることもあるといえる. 